\title{
Analýza pohybové struktury výpadu u dvou výkonnostně odlišných skupin šermírù
}

\section{Analysis of movement structure of the fencing lunge in two different performance-related groups of fencers}

\author{
${ }^{1}$ Štefan Balkó, ${ }^{1}$ Iva Balkó, ${ }^{2}$ Vladimír Süss \\ ${ }^{1}$ Pedagogická fakulta Univerzity J.E.Purkyně, Ústí nad Labem \\ ${ }^{2}$ Fakulta tělesné výchovy a sportu Univerzity Karlovy, Praha
}

\begin{abstract}
Abstrakt:
Studie je zaměrena na kinematickou analýzu pohybové struktury výpadu v šermu u výkonnostně odlišných skupin šermírú. Prvni skupinu (n=7) tvořili elitni šermiřri ČR, kteři jsou v šermu aktivní v prüměru 12 let $( \pm 3,4)$. Ve druhé skupině $(n=7)$ jsou šermíri, kteři jsou v šermu aktivní maximálně 2 roky. Subjekty v naši studii prováděly výpad na vizuálni podnět červené LED diody, která je součástí zařizení Fitrosword. Ukončení výpadu bylo vymezeno zasažením zásahového terče. Cílem studie bylo identifikovat a charakterizovat pohybovou strukturu výpadu. Pro vyhodnocování videozáznamu byl použit software Dartfish 6 TeamPro Data. Šetřením jsme zjistili rozdily ve struktuře jednotlivých fází výpadu mezi sledovanými skupinami šermírù. Byl zjištěn rozdíl v reakční době pri výpadu, rychlostí extenze v loketním kloubu a v rozsahu realizovaného pohybu. Výsledky naši studie mohou posloužit trenérům šermu, kteři je při optimálním pedagogickém a metodickém působeni mohou úspěšně aplikovat v tréninkovém procesu. Mohou pomoci při zvyšování výkonnosti mladých a začinajících šermírùu, kteři uplatni pohybovou strukturu výpadu elitních šermírù.
\end{abstract}

\section{Abstract:}

This study is focused on kinematic analysis in fencing lunge of different performance-related groups offencers. The first group $(n=7)$ consists of elite fencers of the Czech Republic, who are active in fencing an average of 12 years $( \pm 3,4)$. In the second group $(n=7)$, there are fencers who are active in fencing up to two years. Subjects of our study performed lunge on a visual stimulus of LEDs, which is part of the Fitrosword device. The end of lunge was defined by hit of the target. The aim of this study was detection and charactrerization of movement structure in fencing lunge. Video recording and Dartfish TeamPro 6 Data software were used to evaluation of kinematic the lunge. The investigation revealed significant differences in the structure of individual phases of the lunge given to monitored groups of fencers. Between the the groups of fencers was identified difference in reaction time, speed of extension at the elbow joint and range of the movement in lunge. The results of our study may be useful for coaches who may this results due optimal pedagogical and methodological influence successfully applied in the training process. We assume that they can help in improving the performance of young and novice fencers who take into account the movement structure of lunge used by elite fencers.

Klićová slova: vizuální podnět, kinematická analýza, tréninkový proces, elitní šermír

Key words: visual stimuli, kinematic analysis, training process, elite fencer

Výzkum byl realizován za podpory vysokoškolského výzkumu interni grantovou agenturou při SGS PF UJEP Ústi nad Labem. 


\section{ÚVOD}

Předložená studie je zaměřena na kinematickou analýzu pohybové struktury výpadu elitních šermířu a šermírư začátečníků. Stejně tak jako v řadě jiných sportovních disciplín došlo i v šermu v několika posledních desetiletích k určitému vývoji a modifikaci nároků na sportovní výkon. Současný průběh zápasu ve sportovním šermu může být charakterizován jako neustálý sled akcí, které probíhají velmi rychle a nečekaně vzhledem k prostorovým podmínkám, časovému omezení a pohybu (tempu) soupeře. Akce jsou podstatně rychlejší než ty, které byly uplatňovány před vývojem signalizačních zařízení, dokonale identifikujích zásah soupeře (kord 1937, fleret 1957, šavle 1988). To vedlo ke zvýšení nároků na rychlost a k eliminaci nadbytečných a složitých akcí, které byly uplatňovány v šermu ještě na začátku 30. let minulého století (Trohar̆, 2013).

Pro naše šetření jsme vybrali výpad, tedy relativně koordinačně náročný pohybový akt, který je však díky svému průběhu a malým nárokům na prostor dobře laboratorně analyzovatelný.

Výkon ve sportovním šermu určuje řada faktorů, které musí být ve vzájemné interakci (Barth \& Beck, 2007). Významnou roli zde hraje bezpochyby i úroveň jednoduché i složité reakční doby a rychlostní schopnosti.

Vedle sportovního šermu hraje úroveň reakční doby významnou úlohu např. v boxu, v činnostech brankářu v míčových hrách apod. V některých př́ípadech mohou mít vrcholoví sportovci reakce takřka automatické. To souvisí, jak uvádí Schmidt a Wrisberg (2008), se zkušeností a dlouholetým tréninkem.

$\mathrm{V}$ tréninkovém procesu převládají $\mathrm{v}$ odlišných sportech různé podněty, na které sportovci musí reagovat (Czajkowski, 2005). Pro výkon v šermu je podle Borysiuk (2008) optimální uplatňovat reakce na vizuální a taktilní podněty bez zvýšeného bioelektrického napětí svalů. V př́ípadě šermu jde $\mathrm{v}$ tréninkovém procesu převážně o reakce na specifické činnosti trenéra se zbraní, který předem určí, jak má šermír na daný podnět odpovědět. Šermír je v tréninku i zápase vystaven velkému množství stimulů, ze kterých v co nejkratší době vybírá nejvhodnější odpověd'. Prostřednictvím dlouhodobého působení těchto podnětů, které vedou k realizaci př́islušné pohybové akce, dochází k vytváření specifického účelového pohybového programu, jak uvádí Véle (2006). Pohybový program uložený v paměti je pak realizován svalovým aparátem jako pohyb. Díky častému opakování tohoto pohybového programu dochází k upevnění a zdokonalení jeho kvality. Na tomto základě byla postavena koncepce naší studie, která sledovala př́padné odlišnosti ve struktuře výpadu, který byl realizován na základě vizuální stimulace.

Je obecně známé, že zkušenější sportovci disponují lepší analýzou informací z okolního prostředí. Pohybové projevy těchto sportovců jsou pak efektivnější než u začátečníků. Důležité informace z okolního prostředí vnímáme přímo smyslovými systémy, díky kterým dokážeme s rostoucí zkušeností (tréninkem) lépe vnímat a jednat na základě těchto informací (Schmidt \& Wrisberg, 2008). Vzhledem k tomu, že realizace výpadu souvisí v naší studii s vizuální stimulací, budeme se u sledovaných skupin zabývat i úrovní reakční doby.

Reakční doba (reaction time - RT) je časový interval od vzniku smyslového podnětu k zahájení volní reakce, tj. první svalové kontrakci. Jde tedy o dobu přenosu podnětu z receptoru na efektor. U některých pohybových úkolů je reakční doba delší než čas potřebný k jejich realizaci. Velice často se s touto skutečností setkáváme právě v šermu. Zaznamenaná doba reakce pak obsahuje součet reakční doby a pohybového času (Měkota \& Novosad, 2005). Často je tento součet definován jako celková doba odpovědi organizmu (response time). V našem př́padě jde o celkovou dobu výpadu. Na význam reakční doby při výpadu upozorňuje ve svých studiích Borysiuk (2008a, 2008b).

V předchozích studiích se řada autorů pokusila o identifikaci kinematického profilu výpadu nebo o analýzu časové aktivace vybraných svalů prostřednictvím povrchové elektromyografie u skupin šermírủ s různou výkonností. Ze závěrů těchto studií je zřejmé, že časová aktivace jednotlivých segmentů těla a samotná struktura pohybu je při tomto pohybovém aktu velice důležitá. Prioritní činnost paže se zbraní před výpadovou dolní končetinou je zároveň podle reprezentačních trenérů významným vztahem, který může ovlivnit prováděnou akci (výpad, fleche).

V předložené studii přihlížíme k výsledkům předchozích šetření. Uvedeme některé z nich: Harmenberg, Ceci, Barvestad, Hjerpe, a Nyström (1991) nezjistili rozdíly ani v úrovni reakční doby ani v celkové době výpadu mezi elitními šermíři a začátečníky. Se správným a úspěšným provedením výpadu mimo jiné souvisí i síla svalů dominantní i nedominantní dolní končetiny (Nyström, Lindwall, Ceci, Harmenberg, Swedenhag, \& Ekblom, 1990; Sapega, Minkoff, Nicholas, \& Valsamis, 1978) a svalová koordinace.

Prostřednictvím povrchové elektromyografie zjistili Williams a Welmsley (2000a), že mezi skupinou elitních a subelitních šermírư existují rozdíly v časové aktivaci sledovaných svalů. Elitní šermíri měli významně rychlejší zahájení činnosti u pěti ze šesti měřených svalů. EMG analýza pak odhalila vysokou shodu svalové koordinace 
vybraných svalů v obou skupinách šermírů. Tento výsledek vznikl pravděpodobně vysokou výkonnostní úrovní obou testovaných skupin. Reakční doba a celková doba odpovědi byla rychlejší u elitních šermiřů než u šermířu nižší výkonnostní úrovně.

V dalším šetření zjistili Williams a Welmsley (2000b), že jako první byl při výpadu u elitních šermířu aktivován m. rectus femoris „Zadní“ dolní končetiny (vzdálenější od terče), dále m. deltoideus pars anterior na výpadové straně (blíže k terči), m. biceps femoris na „zadní“ dolní končetině a m. triceps na výpadové straně. Stejné svaly „přední“ (výpadové) dolní končetiny zahájily činnost později. Tyto výsledky také potvrzují tvrzení Harmenberg et al. (1991), kteří uvádí, že zkušenější šermíři zahajují výpad činností svalů „předni'“ horní končetiny dříve než činností ,přední“ dolní končetiny.

\section{METODIKA}

Výzkumný soubor tvořili elitní šermíři (n=7), kteří mají v aktuálním žebříčku seriálu poháru MČR pozici do 15. místa. Tito šermírí se této sportovní disciplíně věnují v průměru 12 let $( \pm 3,4)$. Druhou skupinu tvoří šermíři $(\mathrm{n}=7)$, které můžeme zahrnout mezi začátečníky vzhledem k době věnované aktivnímu šermu (do 2 let).

Pro měření reakční doby a pohybového času bylo využito zařízení Fitrosword, které bylo vyvinuto reprezentačními trenéry pro sledování rychlosti reakce na vizuální podněty. Pro toto zařízení byl použit software Sword, který vyhodnocuje zvlášt' reakční dobu a pohybový čas. Součtem obou časů získáme celkový čas potřebný pro provedení výpadu (celková doba výpadu, CDV). Součástí systému Fitrosword je zásahový terč $(28 \times 35 \mathrm{~cm})$ s 2,5 cm širokými ocelovými kruhy a jedním středovým kruhem (průměr $5 \mathrm{~cm}$ ), které identifikují zásah (nejnižší hodnota 0 , nejvyšší hodnota 5 ). Ve středu horního okraje tohoto terče jsou umístěny tři LED diody různých barev. $\mathrm{V}$ našem př́padě bylo využito pouze stimulace červenou LED diodou. Další součástí systému Fitrosword je vysoce citlivá vodorovná překážka, na které měla testovaná osoba položen kord FIE BF Uhlmann (váha 400 g) svou nejspodnější částí číšky. Reakční doba byla určena od okamžiku rozsvícení červené LED diody, která je podnětem pro zahájení výpadu, po první svalovou kontrakci (pohyb kordu přes vodorovnou překážku) ,přední“ horní končetiny, v níž se nacházela zbraň. Od tohoto okamžiku je měřen pohybový čas, který je ukončen zasažením zásahového terče či prostoru mimo něj. Při stanovení pohybové vzdálenosti jsme vycházeli ze stejné metodiky jako Williams a Walmsley (2000a, 2000b). Výšku testované osoby jsme vynásobili koeficientem 1,5. Nejbližší část chodidla zadní dolní končetiny měli šermíři před zahájením výpadu položenou na příslušné značce vztažené $\mathrm{k}$ individuální pohybové vzdálenosti. Využitím koeficientu pro určení pohybové vzdálenosti jsme eliminovali možnost ovlivnění výsledků individuálními výškovými rozdíly.

Pro videozáznam byla použita multiformátová AVCHD kamera Panasonic AG-HMC 41 s rychlostí snímkování 50 snímků/sec. V našem případě jsme využili zápisu 720/50p. Kamera byla umístěna ve vzdálenosti 3,5 m od testovaných osob se středem objektivu ve výšce $1,6 \mathrm{~m}$ od podložky. Sledován byl vnitřní úhel mezi paží a předloktím (loketní kloub, maximální extenze $=180^{\circ}$ ) a vnitřní úhel mezi bércem a stehnem (kolenní kloub, maximální extenze $=180^{\circ}$ ). Šermíři prováděli výpad ze střehové pozice.

Pro samotnou analýzu videozáznamu jsme použili software Dartfish 6 TeamPro Data. V tomto programu jsme analyzovali u každé testované osoby vždy 10 pokusů. Aritmetický průměr a směrodatnou odchylku jsme vypočítali u jednotlivých proměnných v programu Microsoft Excel 2010. Jednotlivé pokusy všech subjektů v obou skupinách byly interindividuálně vyrovnané. $Z$ tohoto důvodu jsme hodnotili pouze průměrné pokusy, kdy směrodatná odchylka dosahovala velice nízkých hodnot. Subjekty byly zároveň instruovány, aby každý pokus prováděly v maximální možné rychlosti. Strana, kde měli šermíři zbraň, byla určena jako „přední“ (výpadová). Strana bez zbraně byla označena jako „zadní“ (odrazová).

\section{VÝSLEDKY}

Struktura pohybu byla sledována v několika fázích výpadu podle individuálního pohybového projevu testovaných osob. 
Tab. 1: Zjištěné proměnné - elitní šermíri

\begin{tabular}{|c|c|c|c|c|c|c|c|c|c|}
\hline Sledované proměnné & S1 & S2 & S3 & S4 & S5 & S6 & S7 & $\varnothing$ & SD \\
\hline Výška TO & 186 & 193 & 180 & 173 & 181 & 188 & 195 & 185 & 7,7 \\
\hline PV $[\mathbf{c m}]$ & 279 & 289 & 270 & 259 & 271 & 282 & 292 & 277 & 11,6 \\
\hline CHP x CHZ - před V [cm] & 83 & 36 & 36 & 39 & 46 & 50 & 52 & 49 & 16,4 \\
\hline LKP - před $\mathrm{V}\left[{ }^{\circ}\right]$ & 111 & 90 & 91 & 109 & 90 & 110 & 115 & 102 & 11,3 \\
\hline KKP - před V $\left[{ }^{\circ}\right]$ & 127 & 126 & 133 & 144 & 126 & 129 & 136 & 132 & 6,7 \\
\hline RD [ms] & 267 & 276 & 332 & 265 & 247 & 290 & 245 & 275 & 29,8 \\
\hline CDV [ms] & 618 & 890 & 859 & 746 & 742 & 676 & 738 & 753 & 95,4 \\
\hline $\begin{array}{c}\text { LKP v okamžiku opuštění } \\
\text { podložky CHP }\left[{ }^{\circ}\right]\end{array}$ & 158 & 118 & 151 & 135 & 141 & 126 & 177 & 144 & 20,1 \\
\hline KKP x zásah $\left[{ }^{\circ}\right]$ & 137 & 144 & 134 & 147 & 173 & 155 & 105 & 142 & 20,9 \\
\hline CHP nad podložkou [ms] & 240 & 580 & 420 & 480 & 380 & 400 & 280 & 397 & 115,1 \\
\hline LF (obě CH) [ms] & 0 & 100 & 60 & 140 & 120 & 0 & 60 & 69 & 55,2 \\
\hline CHZ-před V po MRV [cm] & 6 & 48 & 29 & 33 & 21 & 0 & 24 & 23 & 16,2 \\
\hline KKP v MRV $\left[^{\circ}\right]$ & 100 & 71 & 66 & 89 & 73 & 106 & 79 & 83 & 15,3 \\
\hline Extenze KKZ v MRV & ano & ano & ano & ano & ano & ano & ano & $7 / 7$ & \\
\hline $\begin{array}{c}\text { zasažení terče současně s } \\
\text { došlapem CHP }\end{array}$ & ne & ano & ano & ne & ne & ne & ano & $3 / 7$ & \\
\hline $\mathbf{P}$ & ano & ano & ano & ano & ano & ano & ano & $7 / 7$ & \\
\hline doba extenze LKP [ms] & 380 & 340 & 440 & 420 & 460 & 442 & 440 & 417 & 42,5 \\
\hline činnost HKP a DKP [ms] & 120 & 80 & 200 & 120 & 140 & 34 & 300 & 142 & 86,4 \\
\hline
\end{tabular}

Legenda:TO=testovaná osoba, S1-7=subjekt 1-7, PV=pohybová vzdálenost, CHP=přední chodidlo,

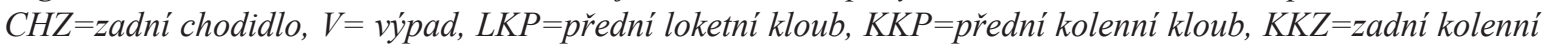
kloub, $R D=$ reakčni doba, $C D V=$ celková doba výpadu, LF=letová fáze, MRV=maximální rozsah výpadu, $P=$ došlap na patu, $H K P=$ prední horni končetina, $D K P=$ předni dolni končetina, $S D=$ směrodatná odchylka

Z tabulky 1 je patrné, že celková doba výpadu u elitních šermířu byla 753 ms. Na celkové době výpadu se podílela reakční doba z $36,5 \%$. Zbylý čas tvořil pohybový čas.

V okamžiku opuštění „předního“ chodidla z podložky měli elitní šermíri úhel v loketním kloubu na straně zbraně v průměru $144^{\circ}$. Od okamžiku, kdy došlo u elitních šermířu k opuštění „předního“ chodidla z podložky, došlo v loketním kloubu k extenzi o $41^{\circ}$. Při zasažení terče byl úhel v kolenním kloubu přední dolní končetiny v průměru $144^{\circ}$. Doba letové fáze, kdy byla obě chodidla bez kontaktu s podložkou, trvala v průměru $69 \mathrm{~ms}$. V tomto ohledu využilo letovou fázi pět ze sedmi elitních šermírũ. Všechny testované osoby zasahovaly terč při maximální extenzi v loketním kloubu na straně zbraně $\left(180^{\circ}\right)$. „Zadní“ chodidlo se v průběhu výpadu posunulo od původní značky v průměru o 23 centimetrů směrem $\mathrm{k}$ terči, což nepochybně souvisí s využitou letovou fází. Průměrně měli elitní šermíři úhel flexe v ,předním“ kolenním kloubu v okamžiku maximálního rozsahu výpadu $83^{\circ}$.

Ve všech případech došlo při provádění výpadu k přetočení chodidla na jeho vnitřní stranu, což nepochybně souvisí se zmíněným posunem „Zadního“ chodidla o 23 centimetrů od původní značky směrem k terči. Ve většině př́ipadů došlo k zasažení terče ještě před došlapem „předního“ chodidla. Ostatní šermíři zasahovali terč současně s došlapem „přední“ nohy. Doba potřebná pro extenzi $\left(90-180^{\circ}\right)$ v „,predním“ loketním kloubu činila 417 ms. Všichni elitní šermíři zahájili výpad podle rozboru videozáznamu nejdříve činností „přední“ horní končetiny a poté přední dolní končetiny. Rozdíl mezi touto dobou činil v průměru 142 ms. 
Tab. 2: Zjištěné proměnné - začátečníci

\begin{tabular}{|c|c|c|c|c|c|c|c|c|c|}
\hline Sledované proměnné & S1 & S2 & $\mathbf{S 3}$ & $\mathbf{S 4}$ & S5 & S6 & S7 & $\varnothing$ & SD \\
\hline Výška TO & 184 & 175 & 167 & 178 & 169 & 180 & 170 & 175 & 6,3 \\
\hline PV $[\mathbf{c m}]$ & 276 & 262 & 251 & 267 & 254 & 270 & 255 & 262 & 9,3 \\
\hline CHP x CHZ - před V [cm] & 42 & 39 & 57 & 51 & 49 & 40 & 31 & 44 & 8,7 \\
\hline LKP - před V $\left[{ }^{\circ}\right]$ & 107 & 141 & 107 & 125 & 101 & 112 & 115 & 115 & 13,6 \\
\hline KKP - před V [ $\left.{ }^{\circ}\right]$ & 145 & 121 & 137 & 125 & 130 & 128 & 123 & 130 & 8,5 \\
\hline RD [ms] & 283 & 356 & 325 & 322 & 349 & 400 & 350 & 341 & 36,1 \\
\hline CDV $[\mathrm{ms}]$ & 834 & 780 & 705 & 727 & 851 & 705 & 741 & 763 & 60 \\
\hline $\begin{array}{c}\text { LKP v okamžiku opuštění } \\
\text { podložky CHP }\left[{ }^{\circ}\right]\end{array}$ & 100 & 141 & 114 & 125 & 97 & 115 & 114 & 115 & 14,9 \\
\hline KKP x zásah $\left[{ }^{\circ}\right]$ & 85 & 121 & 114 & 136 & 129 & 124 & 110 & 117 & 16,6 \\
\hline CHP nad podložkou [ms] & 420 & 400 & 180 & 340 & 300 & 240 & 400 & 326 & 90,7 \\
\hline LF (obě CH) [ms] & 0 & 0 & 0 & 0 & 0 & 0 & 0 & 0 & 0 \\
\hline CHZ-před V po MRV [cm] & 0 & 11 & 0 & 21 & 0 & 14 & 0 & 6,6 & 8,7 \\
\hline KKP $\left.v M R V{ }^{\circ}\right]$ & 78 & 112 & 103 & 101 & 115 & 134 & 90 & 105 & 18,1 \\
\hline Extenze KKZ v MRV & ano & ne & ne & ano & ne & ne & ano & $3 / 7$ & \\
\hline $\begin{array}{c}\text { zasažení terče současně s } \\
\text { došlapem CHP }\end{array}$ & ne & ne & ne & ne & ne & ne & ne & $0 / 7$ & \\
\hline $\mathbf{P}$ & ano & ne & ano & ano & ano & ano & ano & $6 / 7$ & \\
\hline doba extenze LKP [ms] & 480 & 460 & 680 & 500 & 500 & 620 & 700 & 563 & 101 \\
\hline činnost HKP a DKP [ms] & -120 & -220 & -100 & -140 & -80 & -220 & -240 & -160 & 65,3 \\
\hline
\end{tabular}

Legenda: TO=testovaná osoba, S1-7=subjekt 1-7, PV=pohybová vzdálenost, CHP=přední chodidlo,

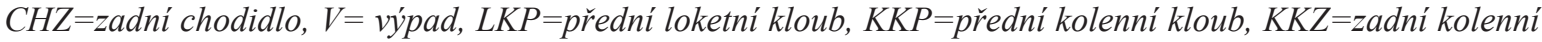
kloub, $R D=$ reakčni doba, $C D V=$ celková doba výpadu, LF=letová fáze, MRV=maximální rozsah výpadu, $P=$ došlap na patu, $H K P=$ předni horní končetina, $D K P=$ přední dolní končetina, $S D=$ směrodatná odchylka

V tabulce 2 vidíme, že celková průměrná doba výpadu u této skupiny byla 763 ms. Na celkové době výpadu se reakční doba podílela ze 46 \%. Žádný šermír ze skupiny začátečníků nevyužil letové fáze pro provedení výpadu, kdy byly obě nohy nad podložkou. V okamžiku opuštění ,předního“ chodidla z podložky byl průměrný úhel v „předním“ loketním kloubu $115^{\circ}$, což bylo o $29^{\circ}$ méně než u skupiny elitních šermírù. Úhel v loketním kloubu v původní střehové pozici a v tento okamžik byl totožný. V okamžiku zásahu terče měla skupina začátečníků úhel v „předním“ kolenním kloubu $117^{\circ}$ (vnitřní úhel mezi bércem a stehnem), což bylo o $25^{\circ}$ méně než u skupiny elitních šermírů. ,Zadní“ chodidlo se posunulo od původní značky v průměru pouze o 6,6 $\mathrm{cm}$. U elitních šermírù byla tato vzdálenost o $16,4 \mathrm{~cm}$ delší. Všechny testované osoby v této skupině měly při výpadu vždy jednu nohu v kontaktu s podložkou, a nedošlo tedy $\mathrm{k}$ letové fázi. V maximálním rozsahu výpadu byl u této skupiny úhel v kolenním kloubu ,„přední“ dolní končetiny $105^{\circ}$, což bylo o $22^{\circ}$ více než u elitních šermírú. Pouze dva subjekty této skupiny přetočily „zadní“ chodidlo na vnitřní stranu. Ve zbývajících případech byla „zadni““ noha v kontaktu s podložkou. Oproti elitním šermířum všechny testované osoby této skupiny nejdříve došláply „předním“ chodidlem, a poté zasáhly terč. Při zásahu terče neprovedla většina začátečníků maximální extenzi $\left(180^{\circ}\right)$ v „,predním“ loketním kloubu. Doba potřebná pro jejich „maximální“ extenzi v „předním“ loketním kloubu činila 563 ms. 


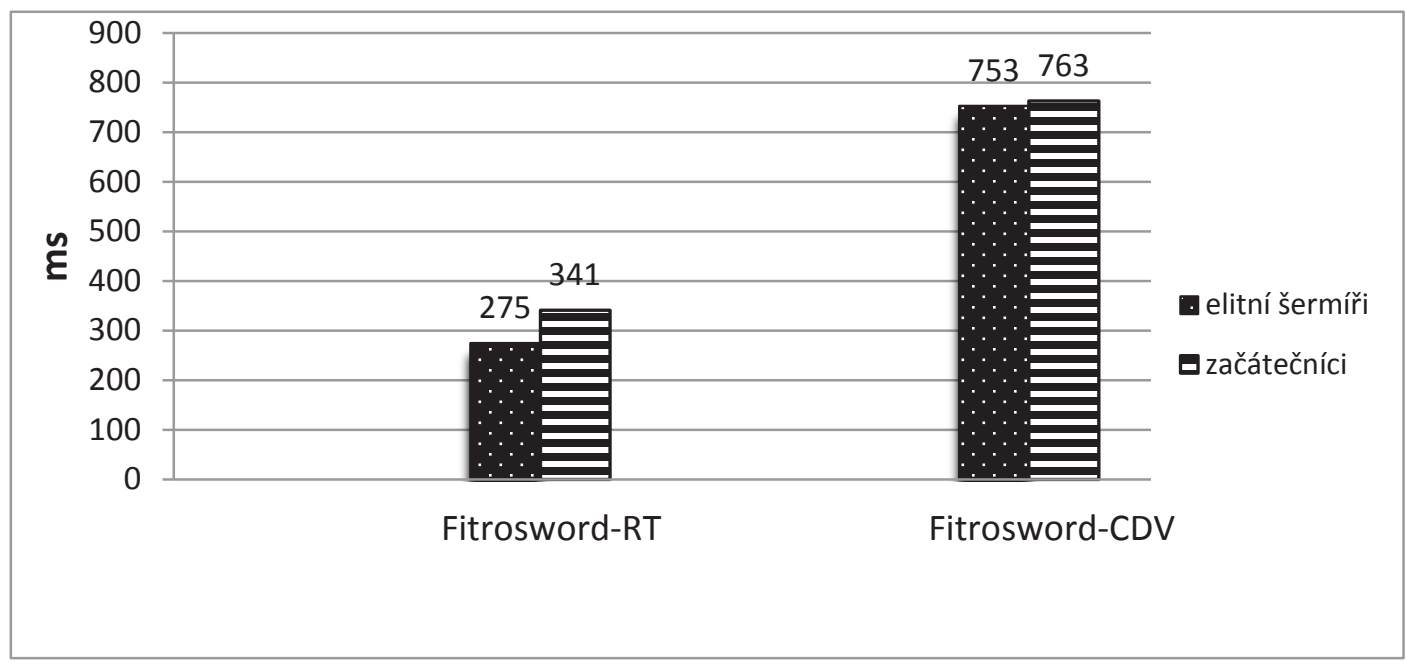

Obr. 1: Odpověd’ organizmu na vizuální stimulaci

Legenda: $R T=$ reakční doba, $C D V=$ celková doba výpadu (reakční čas + pohybový čas výpadu)

Na obrázku 1 je vidět, že elitní šermíři měli nižší hodnoty reakční doby. Celková doba výpadu (součet reakční doby a pohybového času) byla u obou skupin prakticky totožná.

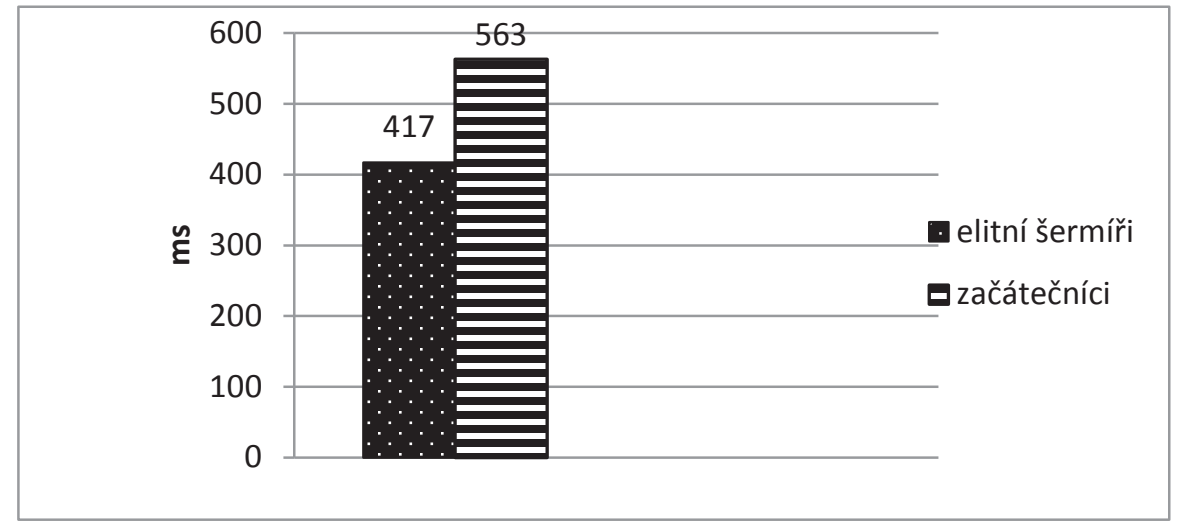

Obr. 2: Čas potřebný pro extenzi v „předním“ loketním kloubu

Z obrázku 2 je patrné, že elitní šermíri potřebovali výrazně kratší dobu pro maximální extenzi v loketním kloubu na straně, kde byla zbraň.

\section{DISKUSE}

Předpokládali jsme, že mezi sledovanými skupinami šermírů bude zjištěn rozdíl v pohybové struktuře výpadu realizovaného na základě vizuální stimulace. Vycházeli jsme z publikací Schmidt a Wrisberg (2008), Vaverky (2011) a Véleho (2006), kteří uvádějí, že díky tréninkové praxi se u sportovců různých sportovních disciplín vytváří a upevňuje efektivní pohybový program pro realizovaný pohyb. V našem šetření byly v tomto ohledu identifikovány rozdíly v pohybové sktruktuře výpadu, a můžeme tedy usuzovat na „optimální“ pohybovou strukturu sledovaného pohybu uplatňovanou elitními šermíři, kteří jsou v šermu aktivní podstatně déle než skupina začátečníků.

Výsledky naší studie jasně poukazují na fakt, že zkušenější šermíři zahajují výpad činností paže, v níž je držena zbraň. Časový rozdíl mezi činností „přední“ dolní končetiny a „přední“ horní končetiny byl u méně zkušených šermírù v průměru 160 ms. Zároveň je nutné dodat, že u této skupiny pohyb zahájila „přední“ dolní končetina. U elitních šermířu předcházela činnost paže se zbraní před činností „,préední“ dolní končetiny v průměru o 142 ms. Podobné výsledky vztažené ke zkušeným šermírům jsou prezentovány např́iklad ve studii 
Harmenberg et al. (1991) nebo Williams a Walmsley (2000a, 2000b). Elitní šermíři v naší studii tedy zahájili oproti začátečníkům extenzi v loketním kloubu „přední“ horní končetiny výrazně dříve.

Rychlost výpadu měřeného od podnětu po zásah (CDV) byla u obou skupin takřka totožná. Z tohoto zjištění můžeme usuzovat na význam svalové koordinace a reakční doby při výpadu. Mezi sledovanými skupinami šermírů byly zjištěny rozdíly v hodnotách reakční doby. Elitní šermíři reagovali na vizuální podnět v průměru o 66 ms rychleji než začátečníci. Reakční doba se u elitních šermířo̊ podílela na celkové době výpadu z 36 \% a u začátečníků ze 46 \%. Toto zjištění odpovídá výsledkům studie Williams a Walmsley (2000a, 2000b), kteří zjistili, že u elitních šermírů se reakční doba podílí na celkové době výpadu ze 40 \% a u subelitních z 66 \%. Vzhledem k tomu, že signalizační zařízení identifikující zásah je nastaveno tak, že současný zásah obou šermířu registruje do $50 \mathrm{~ms}$, můžeme považovat zjištěný rozdíl za velice důležitou informaci, která může ovlivňovat výsledek zápasu. V případě, že jeden ze šermířù zasáhne druhého po tomto časovém úseku, vyhodnotí zařízení platný zásah pouze tomu šermíři, který zasáhl cíl (soupeře) jako první.

Na základě výše uvedených skutečností tedy můžeme usuzovat na význam činnosti jednotlivých segmentů těla při výpadu posuzovaného od jeho zahájení ze střehové pozice po zasažení cíle (v našem případě terče). Studií zaměřenou na 3D analýzu výpadu zjistili Gutiarrez-Davila, Rojas, Antonio, \& Navarro (2013), že mezi skupinou elitních a subelitních šermírư je rozdíl v pohybové vzdálenosti výpadu (vzdálenost provedeného výpadu) a časové posloupnosti vybraných segmentů těla při výpadu. Z naší studie vyplývá, že elitní šermíři využívají při výpadu letovou fázi, kdy jsou obě nohy mimo podložku, zatímco začátečníci měli vždy jednu nohu v kontaktu s podložkou. Od původní značky, určující pohybovou vzdálenost, se elitní šermíři oproti začátečníkům posunuli o 9,8 cm blíže k terči. Toto zjištění potvrzuje výsledek studie Gholipour, Tabrizi, a Farahmand (2008), že výpad realizovaný elitními šermíŕi byl průměrně o $15 \mathrm{~cm}$ delší než u šermíruo začátečníků. Geil (2002) ve své studii zjistil, že při komparaci použití sálové a šermířské obuvi dochází př̀ použití sálové obuvi ke zvyšování rozsahu (délky) výpadu. Toto zjištění mohlo mít vliv i na výsledky naší studie. V souvislosti s rychlostí výpadu zjistili kinematickou analýzou Sillero, Saucedo, López, De Antonio, a De Quel (2008), že při vnitřní i vnější rotaci kolena zadní dolní končetiny nebyl zjištěn rozdíl v rychlosti provedení výpadu.

Rotací kolenního a kyčelního kloubu při výpadu prostřednictvím 3D analýzy se zabývali i Sinclair a Bottoms (2013a). Některé studie se zabývaly i zjišt’ováním rozdílů v kinematickém profilu výpadu mezi muži a ženami. Výsledky studie Sinclair a Bottoms (2013b) poukazují na fakt, že ve sledovaném pohybu nebyl zjištěn rozdíl v rychlosti výpadu ani $\mathrm{v}$ dalších sledovaných proměnných ve vztahu k pohlaví. Na rychlost výpadu má podle Stewart a Kopetka (2005) vliv i maximální rychlost pohybu lokte paže se zbraní a obou kolen.

Rozdíly mezi skupinami byly zjištěny i v př́padě rychlosti extenze v loketním kloubu paže se zbraní po výskytu podnětu. Elitní šermíŕi provedli maximální extenzi v loketním kloubu o 146 ms rychleji než začátečníci. V tomto ohledu musíme zmínit, že skupina začátečníků (z větší části) v naší studii nezasahovala zásahový terč v maximální $\left(180^{\circ}\right)$ extenzi v loketním kloubu. Př́ípadné opoždění tohoto segmentu může negativně ovlivnit výkon v zápase. Výsledky odpovídají závěrům Bottoms, Greenhalgh, \& Sinclair (2013), že s rychlostí ruky se zbraní souvisí další proměnné (např. flexe v kolenním kloubu zadní DK před výpadem, flexe v kyčelním kloubu na výpadové i odrazové DK). Rozdíly v rychlosti a zrychlení vybraných segmentů těla při výpadu potvrzují i výsledky studie Gutierrez-Davila et al. (2013). Autoři rovněž svými závěry dokládají, že při výpadu měli elitní šermíři vyšší rychlost a zrychlení sledovaného pohybu oproti šermírům méně zkušeným.

\section{ZÁVĚR}

Kritériem pro úspěšné zasažení soupeře $\mathrm{v}$ průběhu zápasu prostřednictvím výpadu je správné načasování útoku, optimální časová aktivace zúčastněných svalů a činnost jednotlivých segmentů těla. Při analýze intraindividuálních pokusů jsme neodhalili výrazné odchylky v provedení výpadu ani u elitních šermiřů ani u začátečníků. Rozdíly v pohybové struktuře výpadu však byly zjištěny mezi sledovanými skupinami šermířu.

Rychlost, s jakou je výpad realizován, může s největší pravděpodobností souviset s výsledným výkonem v zápase. Z předložené studie je však zřejmé, že ačkoli nebyl zjišsěn rozdíl v celkové době výpadu, existují v pohybové struktuře výpadu rozdíly, které souvisí s činností vybraných segmentů těla.

Na základě výše zmíněných proměnných a variabilitě zápasu, kdy šermír musí reagovat adekvátně na vyvíjející se situaci, nelze přesně vymezit optimální model pohybové struktury výpadu v zápase. V průběhu zápasu totiž dochází k situacím vyžadujícím prodloužení pohybů, což může ovlivnit zažité pohybové programy při provádění výpadu. 
Výsledky této studie mohou být užitečné pro trenéry, kteří je díky optimálnímu pedagogickému a metodickému působení mohou úspěšně aplikovat v tréninkovém procesu. Předpokládáme, že mohou pomoci při zvyšování výkonnosti mladých a začínajících šermírůn, kteří uplatní pohybovou strukturu výpadu elitních šermířu. V tréninkovém procesu je nezbytné věnovat pozornost ovlivňování reakční doby a modelaci pohybové struktury výpadu, který je jedním z nejčastěji využívaných útoků v průběhu zápasu v šermu. Věříme, že výsledky mohou být užitečné při konstrukci dalších podobně zaměřených studií, které budou řešit aktivaci vybraných svalů při výpadu prostřednictvím povrchové elektromyografie.

\section{LITERATURA}

Barth, B., \& Beck, E. (2007). The complete guide to fencing. Oxford: Meyer and Meyer.

Borysiuk, Z. (2008a). The signifikance of sensorimotor response components and EMG signals depending on stimuli type in fencing. Acta Universitatis Palackianae Olomucensis Gymnica, 38(1), 43-52.

Borysiuk, Z. (2008b). Psychomotor reactions in fencing dependence of stimuli type. Revista Brasileira de Cineantropometria \& Desempenho Humano, 10(3). 223-229.

Bottoms, L., Greenhalgh, A., \& Sinclair, J. (2013). Kinematic determinants of weapon velocity during the fencing lunge in experienced épée fencers. Acta of Bioengineering and Biomechanics, 15(4), 109-113.

Czajkowski, Z. (2005). Understanding Fencing: the unity and practise. New York: SKA Swordplay Books.

Geil, D. M. (2002). The role of footwear on kinematics and plantar foot pressure in fencing. Journal of Applied Biomechanics, 18, 155-162.

Gholipour, M., Tabrizi, A., \& Farahmand, F. (2008). Kinematics analysis of lunge fencing using stereophotogrametry. World Journal of Sport Sciences 1(1), 32-37.

Gutierrez-Davila, M., Rojas, F. J., Antonio, R., \& Navarro, E. (2013). Response timing in the lunge and target change in elite versus medium-level fencers. European Journal of Sport Science, 13(4), 364-371

Harmenberg, J., Ceci, R., Barvestad, P., Hjerpe, K., \& Nyström, J. (1991). Comparison of different tests of fencing performance. International Journal of Sports Medicine, 12, 573-576.

Cheris, E. (2002). Fencing. Step to Success. Champaign: Human Kinetics.

Měkota, K., \& Novosad, J. (2005). Motorické schopnosti. Olomouc: FTK UPOL.

Nyström, J., Lindwall, O., Ceci, R., Harmenberg, J., Swedenhag, J., \& Ekblom, B. (1990). Physiological and morphological characteristics of world class fencers. International Journal of Sports Medicine, 11(2), 136-139. Sapega, A., Minkoff, J., Nicholas, J. A., \& Valsamis, M. (1978). Sport-specific performance factor profiling. Fencing as a prototype. American Journal of Sports Medicine, 6, 232-235.

Sillero, M., Saucedo, F., López, E., De Antonio, R., \& De Quel, O.M. (2008, February). Analysis of the rear leg rotation movement during the fencing lunge. Fencing, Science \& Technology. 1 st International congress on science and technology in fencing, Barcelona.

Sinclair, J., \& Bottoms, L. (2013a). Methods of determining hip joint centre: Their influence on the 3-d kinematics of the hip and knee during the fencing lunge. Human Movement, 14(3), 229-237.

Sinclair, J., \& Bottoms, L. (2013b). Gender differences in the kinetics and lower extremity kinematics of the fencing lunge. International Journal of Performance Analysis in Sport, 13(2), 440

Schmidt, R.A., \& Wrisberg, C.A. (2008). Motor learning and performance: a situation - based learning approach, Champaign: Human Kinetics.

Stewart, S. I., \& Kopetka, B. (2005). The kinematic determinants of speed in the fencing

lunge. Journal of Sports and Science, 23(2), 105

Trohař, R. (2013). Začínáme šermovat kordem. Praha: Danit.

Vaverka, F. (2011). Vliv vybraných faktorů na presnost jednoduchého pohybu. Lateralita, rychlost, zraková kontrola, zátěž, rozsah pohybu. Ostrava: Universitas Ostraviensis.

Véle, F. (2006). Kineziologie. Přehled klinické kineziologie a patokineziologie pro diagnostiku a terapii poruch pohybové soustavy. Praha: Triton.

Williams, L.R.T., \& Walmsley, A. (2000a). Response amendment in fencing: differences between elite and novice subjects. Perceptual and Motor Skills, 91, 131-142.

Williams, L.R.T., \& Walmsley, A. (2000b). Response timing and muscular coordination in fencing: A comparison of elite and novice fencers. Journal of Science and Medicine in Sports, 3(4), 460-475. 